\title{
Asset Focus and Performance of J-REITs: A Comparison between Diversification and Specialization
}

\author{
Toshiki MIGIHASHI ${ }^{*}$, Takahiro OHNO \\ ${ }^{a}$ Graduate School of Creative Science and Engineering, Waseda University \\ 3-4-1 Okubo, Shinjuku-ku, Tokyo 169-8555 Japan
}

\begin{abstract}
While diversified J-REITs that invest in multiple property sectors retain the largest share since the inception of the market, specialized J-REITs have gradually gained presence. The increasing share of specialized J-REITs could be a rational movement if we can verify their superior performance against diversified J-REITs.

This research tries to compare diversified and specialized J-REITs through operational asset-focused $J$-REITs to determine the presence of different risk-return relationships between them using actual market data of 48 months. We choose five J-REITs from three sub-asset categories for our data analyses.

From actual market data, we find no evidence of superior abnormal returns in either hotel- or healthcare-focused J-REITs vis-à-vis diversified J-REITs. For systematic risk, we find significantly lower results with respect to the three sub-asset categories, with no significant difference between them. Furthermore, we construct a simulated diversified J-REIT using five specialized J-REITs, and find that dynamic asset allocation has the potential to outperform existing diversified J-REITs. These results are not fully consistent with those in the previous studies in the United States, but they may indicate a unique phenomenon, at least in the given period, in the J-REIT market.
\end{abstract}

Keywords: diversified J-REIT, specialized J-REIT, risk-return relationships, abnormal return, systematic risk, synthetic diversified J-REIT, efficient frontier, dynamic asset allocation

\section{Introduction}

\subsection{Diversified and Specialized REITs}

The J-REIT market has been growing annually since its inception in 2001. At the end of December 2017, there were 59 listed J-REITs, with the second highest market capitalization following the United States. Until now, "diversified" J-REITs investing in three or more sub-asset classes accounted for the largest proportion of J-REITs and total market capitalization. As the market developed, they added various types of sub-assets as investment targets, which are held by both "specialized" (those focusing on one particular sub-asset category) and diversified J-REITs.

In the United States, where REITs began, the market was initially composed of mostly diversified REITs, but with its expansion specialized REITs gradually gained presence. According to Table 1, specialized REITs accounted for $74 \%$ of REITs and $88 \%$ of market capitalization, while diversified REITs accounted for less than $10 \%$ of the market in the United States as on November 30, 2017.

Recently, J-REITs specializing in operational assets that require in-depth professional management capabilities have been increasing. Hotels and healthcare facilities are typical examples of operational assets.
Table 1 U.S. REIT: Number of REITs and market capitalization by property sector

\begin{tabular}{|c|c|c|c|c|}
\hline \multirow[t]{2}{*}{ Property category } & \multicolumn{2}{|c|}{ \# of REITs } & \multicolumn{2}{|c|}{$\begin{array}{c}\text { Market } \\
\text { capitalization }\end{array}$} \\
\hline & $\#$ & $\%$ & \$’M & $\%$ \\
\hline Diversified & 17 & $8.4 \%$ & 64,800 & $5.9 \%$ \\
\hline Specialized: & 149 & $73.8 \%$ & $1,001,400$ & $88.2 \%$ \\
\hline Office & 22 & $10.9 \%$ & 101,620 & $9.5 \%$ \\
\hline Industrial & 11 & $5.4 \%$ & 76,101 & $6.2 \%$ \\
\hline Retail & 30 & $14.9 \%$ & 180,931 & $16.1 \%$ \\
\hline Residential & 20 & $9.9 \%$ & 148,303 & $13.6 \%$ \\
\hline Lodging/Resorts & 17 & $8.4 \%$ & 57,635 & $4.9 \%$ \\
\hline Self-Storage & 5 & $2.5 \%$ & 58,299 & $5.0 \%$ \\
\hline Healthcare & 19 & $9.4 \%$ & 101,915 & $10.1 \%$ \\
\hline Timber & 4 & $2.0 \%$ & 33,275 & $2.8 \%$ \\
\hline Infrastructure & 6 & $3.0 \%$ & 131,431 & $10.4 \%$ \\
\hline Data Centers & 5 & $2.5 \%$ & 71,995 & $6.1 \%$ \\
\hline Specialty & 10 & $5.0 \%$ & 39,384 & $3.6 \%$ \\
\hline $\begin{array}{l}\text { Mortgage } \\
\text { (debt REIT) }\end{array}$ & 36 & $17.8 \%$ & 66,057 & $5.9 \%$ \\
\hline TOTAL & 202 & $100 \%$ & $1,132,257$ & $100 \%$ \\
\hline
\end{tabular}

Data as of November 30, 2017

Source: NAREIT REIT Watch December 2017 [1]

At the end of December 2017, the Tokyo Stock Exchange (TSE) listed five hotel-focused and three healthcare-focused J-REITs, as indicated in Table 2. Most of them have gone public since 2011.

\footnotetext{
* \&orresponding author: t-migihashi@moegi.waseda.jp
} 
Table 2. J-REIT Market: Number of REITs and market capitalization by property sector

\begin{tabular}{c|rc|rc}
\hline \multirow{2}{*}{$\begin{array}{c}\text { Property } \\
\text { category }\end{array}$} & \multicolumn{2}{|c|}{$\begin{array}{c}\text { No. of } \\
\text { J-REITs }\end{array}$} & \multicolumn{2}{c}{ Market capitalization } \\
\cline { 2 - 5 } & No. & $\%$ & \multicolumn{1}{c}{ JPY (M) } & $\%$ \\
\hline Diversified & 19 & $32.2 \%$ & $3,958,903$ & $34.5 \%$ \\
\hline Specialized: & 38 & $64.4 \%$ & $7,183,884$ & $62.6 \%$ \\
\hline Office & 12 & $20.3 \%$ & $3,024,620$ & $26.4 \%$ \\
\hline Commercial & 4 & $6.8 \%$ & $1,097,201$ & $9.6 \%$ \\
\hline Residential & 8 & $13.6 \%$ & $1,176,790$ & $10.3 \%$ \\
\hline Logistics & 6 & $10.2 \%$ & $1,295,770$ & $11.3 \%$ \\
\hline Hotels & 5 & $8.5 \%$ & 542,793 & $4.7 \%$ \\
\hline Healthcare & 3 & $5.1 \%$ & 46,710 & $0.4 \%$ \\
\hline Complex & 2 & $3.4 \%$ & 332,619 & $2.9 \%$ \\
\hline TOTAL & 59 & $100 \%$ & $11,475,406$ & $100 \%$ \\
\hline
\end{tabular}

Data as of December 29, 2017

Source: IBRC Inc. [2]

Figure 1 depicts the overall relationship between the expected return generally required by investors and the operational nature of each sub-asset. It illustrates the investors' expectations of higher returns with an increase in the asset management expertise required for investment. As shown in the figure, operational assets are expected to have higher yield than others. This is why we chose operational asset-focused J-REITs to compare with diversified J-REITs. If specialized JREITs really have unique risk-return relationships, they would be most likely to be observed.

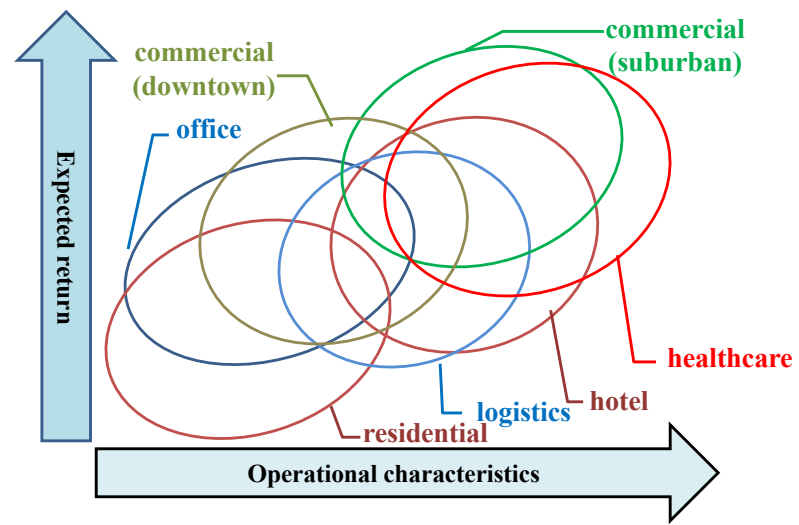

Figure 1. Correlation between operational characteristics and expected returns (Created by the author using data from the $37^{\text {th }}$ Japanese Real Estate Investor Survey by the Japan Real Estate Institute [3])

\subsection{Objectives}

Most asset managers of specialized J-REITs insist that their lack of diversification is justifiable owing to their expertise in specific property categories for enhancing returns. However, according to the efficient market hypothesis, the performance of specialized JREITs should not be significantly different after adjusting for systematic risks. Yet intuitively, healthcarefocused J-REITs have been experiencing less volatile price fluctuations to some extent than diversified JREITs or the market as a whole.

We can also observe some differences in the price volatilities between hotel- and healthcare-focused J-
REITs, despite their common characteristics of investing in operational assets. This research tries to compare diversified and specialized J-REITs through operational asset-focused J-REITs to determine the presence of different risk-return relationships between them using actual market data of 48 months. For this objective, we empirically investigate a hypothesis that "J-REITs focused on operational assets statistically outperform diversified J-REITs, indicating that specialization in a particular sub-asset yields better results". Further, this study constructs a simulated diversification by combining existing specialized J-REITs. Comparing the simulated diversified J-REIT to existing J-REITs may provide some useful implications for investors who are not satisfied with the current sub-asset mix provided by readymade diversified J-REITs.

\section{Literature Review}

There is a large volume of extant studies on the leading REIT market of the United States, which compares specialized and diversified REITs or property portfolios, and analyzes various factors that affect riskreturn relationships, agency problems, issues associated with disclosure, effects of monetary policies, and so on. These studies are helpful references for analyzing JREITs.

Gelner and Miller [4] listed three major reasons for the increasing specialization trend, including growing investor preference in $1990 \mathrm{~s}$ to make their own diversification decisions. Kojima [5] surveyed 100 articles on REITs published after 2010 in three major real estate academic journals, and classified them by theme, to sort the development of research on REITs, in particular, their pricing, and risk analyses. Kojima [5] noted that the relationship between performance and diversification strategy remains a debated issue. Capozza and Seguin [6] argued that the diversification of REITs based on property types reduces their value, as the additional expenses to manage multiple categories of assets offset the merits of the diversification. Benefield et al. [7] compared 60 specialized and 15 diversified REITs between 1995 and 2006, and found that diversified REITs significantly outperformed specialized ones in the first five years. However, the sample diversified REITs chosen by Benefield et al. did not sufficiently represent actual sub-asset category mix of the market at the time. Gallo et al. [8] investigated real estate funds, and found that some property types outperform others during certain periods. They suggested that property composition matters to performance. Ro and Ziobrowski [9] compared diversified and specialized REITs during 1997-2006 in order to examine whether specialized REITs outperform diversified REITs. They employed the capital asset pricing model (CAPM) and Fama-French three-factor model in their analyses, and found no evidence of superior performance associated with specialized REITs. They also found that specialized REITs have significantly higher market risk than diversified REITs. 
Goebel et al. [10] argued that the return, after adjusting for momentum effects, correlates to book-to-market ratio, institutional holding, and liquidity. As for researches on specialized J-REITs, Migihashi and Ohno [11, 12] surveyed hotel- and healthcare-focused J-REITs and revealed that they have unique price volatilities compared to others.

These studies cover not only REITs, but also real estate funds and other property investors. Their conclusions vary depending on the period examined and approaches used. Some studies support the difference in risk-return relationships between property sector specialists and generalists, while others do not.

\section{Analyses and Results}

\subsection{Regression Analyses}

We choose five specialized J-REITs from three subasset categories: three diversified, one hotel-focused, and one healthcare-focused. We based our choice on the size of market capitalization as on December 29, 2017, from those listed before the end of 2012, except for the healthcare-focused REIT, which does not have historical data before 2014. We obtained stock price data from www.k-db.com. Then we conduct two regression analyses, a. and b., as explained below:

a. Estimate the beta of the five specialized J-REITs. We employ the "TOPIX (Tokyo Stock Price Index) Total Return," which is a proxy for the Japanese stock market, as the independent variable for the regression. The data are on a total return basis with dividend receipts included in the calculations.

b. Verify the abnormal returns and systematic risks associated with each of the three categories against the J-REIT market as a whole. We use "TSE REIT Index Total Return" as a proxy of the whole JREIT market. Further, we treat the margins between specialized and diversified types in a similar manner.

Table 3. List of J-REITs used in the regression analyses

\begin{tabular}{lcc}
\hline $\begin{array}{c}\text { Category/J-REIT (Abbreviation /TSE } \\
\text { code) }\end{array}$ & $\begin{array}{c}\text { Listing } \\
\text { (M/Y) }\end{array}$ & $\begin{array}{c}\text { Market } \\
\text { cap } \\
\text { (in JPY } \\
\text { million) }\end{array}$ \\
\hline Diversified: & & \\
\hline United Urban (UUR/8960) & $12 / 2003$ & 495,230 \\
\hline Daiwa House REIT (DHR/8984) & $6 / 2002$ & 452,413 \\
\hline ORIX JREIT (OJR/8954) & $6 / 2002$ & 418,348 \\
\hline Hotel-focused: & $6 / 2006$ & 303,220 \\
\hline Japan Hotel REIT (JHR/8985) & & \\
\hline Healthcare-focused: & $11 / 2014$ & 12,240 \\
\hline $\begin{array}{l}\text { Nippon Healthcare REIT } \\
\text { (NHR/3308) }\end{array}$ & & \\
\hline
\end{tabular}

Data as on December 29, 2017

We use two indices provided by the Japan Exchange Group Data Cloud in a. and b. above. We calculate the total returns of individual J-REITs using publicly available market data. Table 3 summarizes the five $\mathrm{J}$ REITs chosen for the analysis.

As diversified J-REITs actually vary in property sector composition, we checked if the three chosen diversified J-REITs are not heavily biased in their property sector compositions than the overall J-REIT market before the analyses. For instance, DHR, which is one of the diversified J-REITs in the sample, has a rather unique composition than the others. It concentrates on logistics and residential, reflecting its sponsor's businesses. We present two pie charts below.

Figure 2 depicts the composition of all J-REITs as on September 30, 2017 by property type. Office accounts for $30.8 \%$ of all J-REITs, while hotel and healthcare properties represent $9.6 \%$ and $0.2 \%$, respectively.

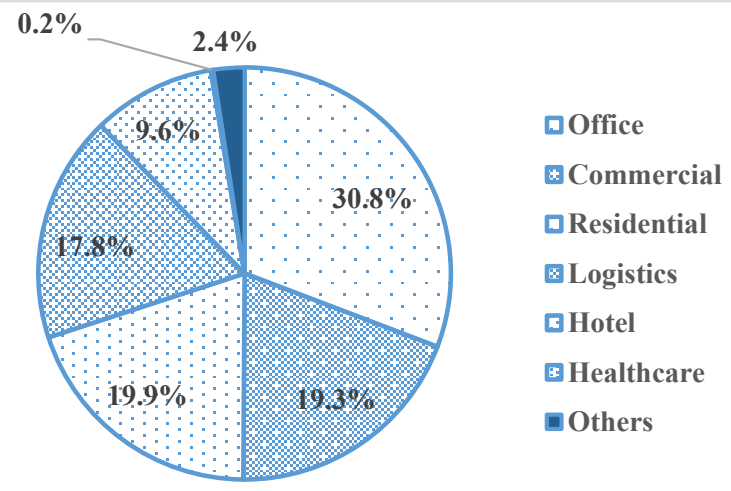

Figure 2. Composition by property sector: All J-REITs (Source: ARES Monthly Report October. 2017 [13])

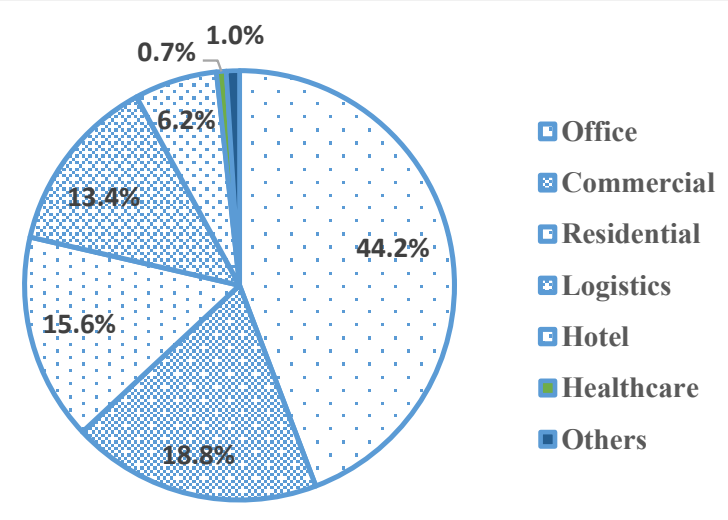

Figure 3. Composition by property sector: Three diversified JREITs (Source: Disclosed information by each JREIT)

Figure 3 indicates the total composition of the three diversified J-REITs. Office, hotel, and healthcare facilities account for $44.2 \%, 6.2 \%$, and $0.7 \%$, respectively. Other major sectors also indicate comparable figures in the overall J-REIT market. Therefore, we can conclude that the property composition of the three selected J-REITs does not deviate heavily from the whole J-REIT market.

Results of Analysis a.: 
Table 4 presents the betas of the five J-REITs estimated using regressions on actual monthly total returns for 48 months from 2013 to 2016, except for NHR, which is for 24 months from 2015 to 2016. As JREITs vary in size, we also calculate the market capitalization-weighted average beta of the diversified category, which is reported in Table 4. The market capitalization in Table 3 is evenly assumed for simplicity throughout the period of analysis. We verify the assumption that healthcare-focused J-REITs have lower volatility, while hotel-focused J-REITs have higher volatility, with diversified J-REITs positioned in the middle.

Table 4. Stock beta of five selected J-REITs

\begin{tabular}{llc}
\hline Category/J-REIT (TSE code) & Beta & $\begin{array}{c}\text { Weighted } \\
\text { average beta }\end{array}$ \\
\cline { 1 - 2 } Diversified (2013-2016): & & \\
\cline { 1 - 2 } UUR (8960) & 0.543 & \\
\hline DHR (8984) & 0.337 & \\
\hline OJR (8954) & 0.456 & \\
\hline Hotels-focused (2013-2016): & & - \\
\hline JHR (8985) & 0.717 & \\
\hline Healthcare-focused (2015-2016): & & - \\
\hline NHR (3308) & 0.210 & \\
\hline
\end{tabular}

Results of Analysis b.:

Using CAPM, we investigate whether diversified, hotel-focused, or healthcare-focused J-REITs have significant abnormal returns vis-à-vis the overall J-REIT market. We conduct the same analysis for operational asset-focused (hotel- or healthcare-focused) J-REITs versus diversified J-REITs. In this analysis, we use the CAPM equations (1) and (2) given below. We model these equations on those used by Ro and Ziobrowski [9], and Chiang et al. [14] in comparable contexts.

$R_{p, t}-R_{f, t} \quad=\alpha_{p}+\beta_{p}\left(R_{m, t}-R_{f, t}\right)+\varepsilon_{p, t}$

$R_{\text {ope }, t}-R_{\text {div }, t}$

$=\left(\alpha_{o p e, t}-\alpha_{\text {div }, t}\right)+\left(\beta_{\text {ope }, t}-\beta_{\text {div }, t}\right) R_{m, t}+\left(\varepsilon_{\text {ope }, t}-\varepsilon_{\text {div }, t}\right)$

$\equiv \Delta \alpha_{p}+\Delta \beta_{p}\left(R_{m, t}-R_{f, t}\right)+\varepsilon_{p, t}$

In equation (1), $R_{p, t}$ is the monthly price change ratio of a portfolio (one of the three) in month $t, R_{f, t}$ is the riskfree rate, $R_{m, t}$ is the monthly price change ratio of the TSE REIT Index, and $\varepsilon_{p, t}$ is the error term. Intercept $\alpha_{p}$ measures the monthly abnormal return.

In equation (2), $\left(R_{\text {ope }, t}-R_{\text {div }, t}\right)$ is the incremental return on an operational asset-focused J-REIT portfolio (either of the two) with respect to a diversified J-REIT portfolio in month $t$. Therefore, a positive $\Delta \alpha_{p}$ denotes an incremental average monthly abnormal return on an operational asset-focused J-REIT portfolio if statistical significance can be verified. In our actual calculation, we modify equations (1) and (2) as follows, considering the zero-interest policy of the Bank of Japan from short- to long-term interest rates.

$$
\begin{aligned}
& R_{p, t} \quad=\alpha_{p}+\beta_{p} R_{m, t}+\varepsilon_{p, t} \\
& R_{\text {ope }, t}-R_{\text {div }, t} \\
& =\left(\alpha_{\text {ope }, t}-\alpha_{\text {div }, t}\right)+\left(\beta_{\text {ope }, t}-\beta_{\text {div }, t}\right) R_{m, t}+\left(\varepsilon_{\text {ope }, t}-\varepsilon_{\text {div }, t}\right) \\
& \equiv \Delta \alpha_{p}+\Delta \beta_{p} R_{m, t}+\varepsilon_{p, t}
\end{aligned}
$$

Table 5 summarizes the results of the regression analyses for diversified, hotel-focused, and healthcarefocused J-REIT portfolios.

During the period of analysis, $\alpha_{p}$ does not indicate statistically significant figures for any of the three categories if we set two sigma as a hurdle. This result indicates that there are no abnormal returns on operational asset-focused J-REITs. Therefore, our hypothesis set in section 1 is not verified.

Table 5. Summary of the regression analyses of diversified,

\begin{tabular}{|c|c|c|c|c|c|}
\hline Category & \multicolumn{2}{|c|}{$\begin{array}{l}\alpha_{p} / \Delta \alpha_{p} \\
\text { Parameter } \\
\text { t-statistics }\end{array}$} & \multicolumn{2}{|c|}{$\begin{array}{c}\beta_{p} / \Delta \beta_{p} \\
\text { Parameter } \\
\text { t-statistics }\end{array}$} & $\begin{array}{l}\text { Adjust } \\
\text {-ed } \mathrm{R}^{2}\end{array}$ \\
\hline a. Diversified & $\alpha_{p}$ & $\begin{array}{c}0.31 \% \\
\times 1.05 \\
\end{array}$ & $\beta_{p}$ & $\begin{array}{r}0.95 \\
\times 19.12 \\
\end{array}$ & 0.89 \\
\hline b. Hotel & $\alpha_{p}$ & $\begin{array}{l}1.51 \% \\
\times 1.98 \\
\end{array}$ & $\beta_{p}$ & $\begin{array}{c}0.95 \\
\times 7.24 \\
\end{array}$ & 0.53 \\
\hline (b-a) & $\Delta \alpha_{p}$ & $\begin{array}{l}1.20 \% \\
\times 1.48 \\
\end{array}$ & $\Delta \beta_{p}$ & $\begin{array}{l}-0.01 \\
x-0.06 \\
\end{array}$ & 0.00 \\
\hline $\begin{array}{l}\text { c. Healthcare } \\
\text { (24-month) }\end{array}$ & $\alpha_{p}$ & $\begin{array}{l}-1.60 \% \\
x-1.84 \\
\end{array}$ & $\beta_{p}$ & $\begin{array}{c}0.87 \\
\times 2.75 \\
\end{array}$ & 0.26 \\
\hline (c-a) & $\Delta \alpha_{p}$ & $\begin{array}{l}-1.76 \% \\
x-1.87\end{array}$ & $\Delta \beta_{p}$ & $\begin{array}{c}0.02 \\
\times 0.07\end{array}$ & 0.00 \\
\hline
\end{tabular}
hotel-focused, and healthcare-focused J-REITs to TSE REIT Index Total Return for 48 months from 2013 to 2016.

In terms of market risks, all three sub-asset categories fall below one with statistical significance. The lowest beta, 0.87, belongs to healthcare-focused J-REITs. However, as there is no statistical significance in the margins between diversified and specialized J-REITs, we cannot claim that specialized J-REITs either outperform or underperform diversified J-REITs.

\subsection{Simulated Diversification}

We simulate a diversified J-REIT by mixing five existing specialized J-REITs for two purposes:

(1) To compare risk-return relationships between synthetic and existing diversified J-REITs.

(2) To calculate an efficient frontier of the synthetic diversified J-REIT in order to determine whether it is feasible to outperform existing diversified $\mathrm{J}$ REITs.

As indicated by Figure 3, the top five asset categories represent $92 \%$ of the three largest diversified J-REITs. By mixing five specialized J-REITs chosen from each of the five sub-asset categories, we can replicate a diversified J-REIT that is comparable to existing diversified J-REITs in sub-asset composition. The five categories are office, commercial, residential, logistics, and hotel. We do not include healthcare in the simulated 
diversified portfolio owing to its small share and insufficient historical data than the others.

We chose J-REITs that represent each of the categories by market capitalization from among the JREITs listed before the end of 2012. Our analysis period is from January 2013 to December 2016, with a 48month data series of each J-REIT, which are listed in Table 6 below. The higher beta of hotel-focused J-REITs that we saw in Table 4 is reflected in Table 6 by its higher monthly total returns, as well as a larger standard deviation than the others.

Table 6. Specialized J-REITs used to simulate a synthetic diversified J-REIT

\begin{tabular}{lll}
\hline Category & $\begin{array}{c}\text { Average } \\
\text { monthly } \\
\text { total } \\
\text { return }\end{array}$ & $\begin{array}{c}\text { Standard } \\
\text { deviation } \\
\text { of the } \\
\text { return }\end{array}$ \\
\hline Office-focused: & \\
\hline $\begin{array}{l}\text { Nippon Building Fund } \\
\text { (NBF/8951) }\end{array}$ & $1.22 \%$ & $7.03 \%$ \\
\hline Commercial-focused & $6.37 \%$ \\
\hline Japan Retail Fund (JRF/8953) & $1.31 \%$ \\
\hline Residential-focused: & $6.43 \%$ \\
\hline Advance Residence (AR/3269) & $1.60 \%$ \\
\hline Logistics-focused: & $5.45 \%$ \\
\hline $\begin{array}{l}\text { Japan Logistics Fund } \\
\text { (JLF/8967) }\end{array}$ & $1.42 \%$ \\
\hline Hotel-focused: & $2.94 \%$ \\
\hline Japan Hotel REIT (JHR/8985) & $7.30 \%$ \\
\hline Figures are for a 48-month period from 2013 to 2016
\end{tabular}

Figure 4 plots the risk-return relationship of the five specialized, three diversified, and TSE REIT Index Total Return, making it easier to judge the relative performance of two different investments with the same average monthly returns by simply comparing their standard deviations.

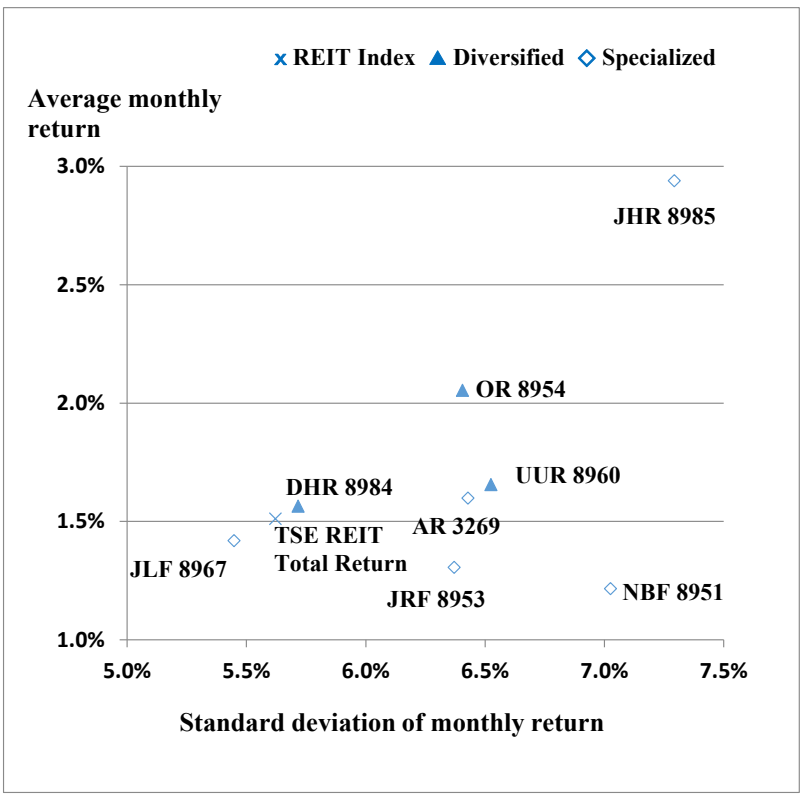

Figure 4. Risk-return relationship, 2013-2016
The three diversified groups generally indicate higher monthly returns, while some of the specialized groups indicate lower returns with higher risks than a diversified group or the TSE REIT Index Total Return.

Next, we determine if a synthetic diversified J-REIT can outperform existing diversified J-REITs by changing the sub-asset allocation. While portfolio returns are calculated simply by weighted average, portfolio standard deviations are not, because covariance between portfolio components matters. We use an optimization function in a spreadsheet to find a series of category mixes with minimum variance for specific monthly returns, drawn as the "efficient frontier" in Figure 5.

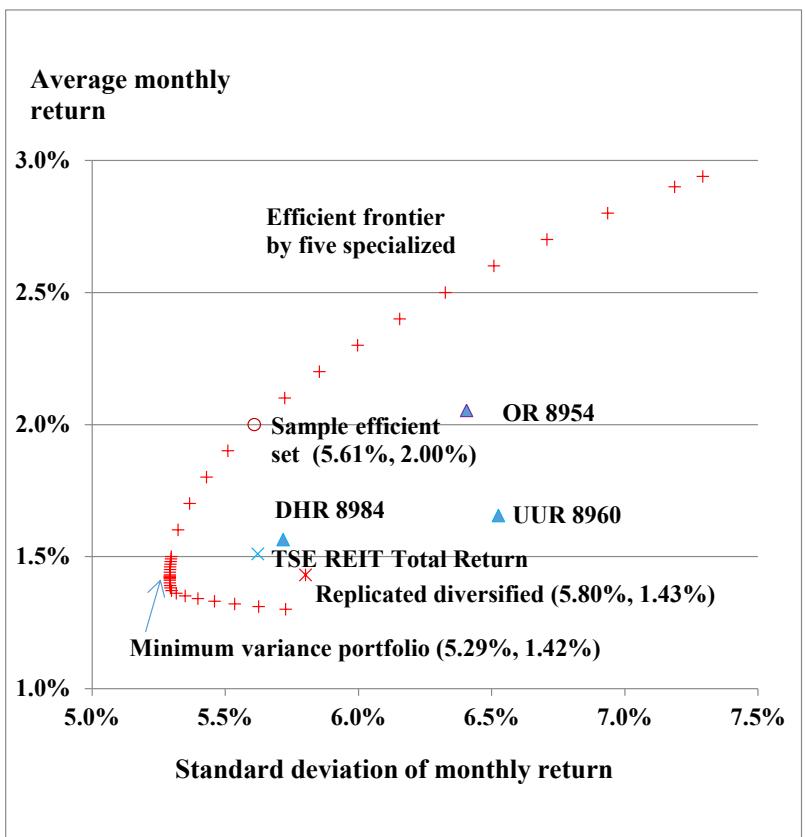

Figure 5. Efficient frontier by five specialized J-REITs

The efficient sets on the frontier apparently indicate the potential for better risk-return relationships than actual diversified J-REITs. Most of them are positioned far above any of the three diversified J-REITs plotted in the figure. For example, a sample efficient set, indicated by a circle on Figure 5, has a better risk-return profile than any of the three diversified J-REITs as described in Table 7. This shows potential of superior performance by a bespoke diversified J-REIT portfolio. Although the efficient frontiers are drawn using past market data that we are already aware of, it can still suggest that a better sub-asset mix can outperform diversified J-REITs by mixing existing specialized J-REITs.

Table 7 Sample efficient set

\begin{tabular}{|c|c|c|c|c|}
\hline $\begin{array}{l}\text { Office } \\
\text { (NBF) }\end{array}$ & $\begin{array}{c}\text { Commercial } \\
\text { (JRF) }\end{array}$ & $\begin{array}{l}\text { Residential } \\
\text { (AR) }\end{array}$ & $\begin{array}{c}\text { Logistics } \\
\text { (JLF) }\end{array}$ & $\begin{array}{l}\text { Hotel } \\
\text { (JHR) }\end{array}$ \\
\hline $4.7 \%$ & $7.7 \%$ & $13.5 \%$ & $36.3 \%$ & $37.8 \%$ \\
\hline \multicolumn{4}{|c|}{ Average monthly total return } & $2.00 \%$ \\
\hline \multicolumn{4}{|c|}{ Standard deviation of the return } & $5.61 \%$ \\
\hline
\end{tabular}

On the other hand, replicated diversified J-REITs appear in an undistinguished position, as indicated by the 
asterisk in the lower middle of the figure. It represents the risk-return relationship of a replicated portfolio with the same sub-asset composition equivalent to that of the top three diversified J-REITs combined, as is shown in Table 8. It even underperforms the TSE REIT Index Total Return, that is, lower return and higher standard deviation than the index. Therefore, simply replicating the sub-asset allocation of existing diversified J-REITs does not necessarily imply that such a simulated diversified J-REIT can perform at the same level.

Table 8 Replicated diversified J-REIT possessing identical sub-asset composition to top three readymade diversified J-REITs.

\begin{tabular}{|c|c|c|c|c|}
\hline \multicolumn{5}{|c|}{ Risk and return - The synthetic replicated diversified J-REITs: } \\
\hline \multicolumn{5}{|c|}{ Portfolio composition } \\
\hline Office & Commercial & Residential & Logistics & Hotel \\
\hline $45.0 \%$ & $19.1 \%$ & $15.9 \%$ & $13.7 \%$ & $6.3 \%$ \\
\hline \multicolumn{4}{|c|}{ Average monthly return } & $1.43 \%$ \\
\hline \multicolumn{4}{|c|}{ Standard deviation of the return } & $5.80 \%$ \\
\hline \multicolumn{5}{|c|}{ Risk and return - TSE REIT Index Total Return: } \\
\hline \multicolumn{4}{|c|}{ Average monthly total return } & $1.51 \%$ \\
\hline \multicolumn{4}{|c|}{ Standard deviation of the return } & $5.62 \%$ \\
\hline
\end{tabular}

\section{Conclusions}

This study aimed to verify whether there are statistically significant differences in the risk-return relationships between diversified, hotel-focused, and healthcare-focused J-REITs. We use actual monthly market data for a 48-month period from 2013 to 2016, and employ CAPM for the analyses.

We consider that specialization in operational assets inevitably incurs additional costs to investors because it requires an in-depth understanding of particular subassets. We understand that the growing tendency for specialization in the J-REIT market can be justified as a rational movement if its performance is significantly better. However, our analyses find no evidence to support this claim associated with operational assetfocused J-REITs. Actual market data do not indicate statistically significant abnormal returns of either hotelor healthcare-focused J-REITS vis-à-vis the diversified type. As for systematic risk, we identify significantly lower figures for all three types of J-REITs. These results are not entirely consistent with those in previous studies in the United States; however, this phenomenon is observed in at least the given periods in the J-REIT market.

Some participants in the market provide qualitative explanations, wherein the increasing trend of specialization reflects investors' preferences of setting their own diversification standards. Most diversified JREITs set target asset allocation by sub-asset and geographic distribution. Their allocation standards are usually static and fixed over a long period. Specialized JREITs can provide investors the opportunity to realize their desired sub-asset allocation. They can construct their preferred sub-asset compositions by mixing existing specialized J-REITs for better performance than simply purchasing readymade diversification. In addition, diversification by mixing specialized J-REITs has clear economic advantages in terms of transactions costs, as it merely involves the trading of listed stocks. On the other hand, setting their own property portfolio mix and changing the composition occasionally may incur large transaction costs for investors, such as property registration charges. Further, as the risk-return relationships of each sub-asset may change, J-REIT investors can conduct dynamic asset allocation, wherein they alter sub-asset compositions over the course of their investment in an economically justifiable manner. As indicated by our analyses, simply replicating existing diversified J-REITs may not compensate for such efforts. We believe that one of the implications of this study is that a dynamic asset allocation of specialized J-REITs over the short- and medium-term, as well as of individual diversified J-REITs, is worth considering because the risk-return relationships among sub-assets vary and change over time. In other words, J-REIT investors may be able to improve risk-return profiles of their portfolio by actively managing sub-asset compositions rather than by considering which J-REIT to purchase.

To conclude, we would like to mention several related issues that we cannot cover in this study. We would like to explore these to broaden the basis of our research in the near future.

(1) An investigation of the U.S. hotel-focused and healthcare-focused REITs for unique or similar characteristics vis-à-vis specialized REITs in other markets or the J-REIT market.

(2) A more in-depth qualitative analysis to explain the increasing trend of specialized REITs.

(3) An investigation covering all listed J-REITs.

(4) Testing asset pricing models other than CAPM, such as Fama-French three-factor model, to broaden the basis of our research.

(5) Analysis over longer or different time periods.

(6) Including factors other than stock price, such as loan-to-value ratio, price-to-book ratio, property sector composition of diversified REITs, sponsor quality, institutional holding, and market capitalization.

\section{References}

[1] The National Association of Real Estate Investment Trusts: REIT Watch December 2017, (2017).

[2] IBRC Inc.: Market Briefing Reports, JapanREIT.com, http:/en.japan-reit.com/report/shutoku/ (accessed January 1, 2018)

[3] Japan Real Estate Institute: The $37^{\text {th }}$ Japanese Real Estate Investor Survey, (2017).

[4] M.D. Geltner, N.G. Miller, J. Clayton, and P. Eichholtz: Commercial real estate analysis and investments, Cincinnati OH South-Western, (2001).

[5] K. Kojima: Critical Review for Studies on REITs in the U.S., Kokusai-gaku Kenkyu (International Studies Research), (2015) 4(1):65-81. 
Asset Focus and Performance of J-REITs: A Comparison between Diversification and Specialization

[6] D.R. Capozza, and P.J. Seguin: Focus, Transparency and Value: The REIT Evidence, Journal of Real Estate Economics, (1999) 27(4):587-619.

[7] J.D. Benefield, R.I. Anderson, and L.V. Zumpano: Performance Difference in Property-Type Diversified Versus Specialized Real estate Investment Trusts, Review of Financial Economics, (2008) 18(2):70-79.

[8] J.G. Gallo, L.J. Lockwood, and R.C. Rutherford: Asset Allocation and the Performance of Real Estate Mutual Fund, Real Estate Economics, (2000) 28(1):165-184.

[9] S.H. Ro, and A.J. Ziobrowski: Does Focus Really Matter? Specialized vs. Diversified REITs, Journal of Real Estate Finance and Economics, (2011) 42(1):68-83.

[10] P.R. Goebel, D.M. Harrison, J.M. Mercer, and R.J. Whitby: REIT Momentum and Characteristics-
Related REIT Returns, Journal of Real Estate Finance and Economics, (2013) 47(3):564-581.

[11] T. Migihashi, and T. Ohno: Appropriate Disclosure of Risk Factors associated with Investments in Healthcare Properties, International Journal of Japan Association for Management Systems, (2017) 9.1: 9-27.

[12] T. Migihashi, and T. Ohno: Asset Focus and Performance of J-REITs, International Conference for Business and Information 2017, Japan Association for Management Systems, (2017).

[13] The Association for Real Estate Securitization: ARES Monthly Report October 2017, (2017)

[14] C.K. Chiang, K. Kozhevnikov, M.L. Lee, and C.H. Wisen: Further Evidence on the Performance of Funds of Funds: The Case of Real Estate Mutual, Real Estate Economics, (2008) 36(1):47-61. 
